PAEDAGOGIA CHRISTIANA

2/26(2010) - ISSN 1505-6872

Jacek Salij

Warszawa

\title{
Dialogiczny wymiar wiary religijnej
}

\section{Czym różni się wiara od wierzeń?}

Istnieją religie ${ }^{1}$, w których dialog ludzi z Bogiem nie jest czymś ważnym, a wydaje się, że w ogóle nie jest praktykowany. Są to religie, których istota polega na wypełnianiu uświęconych przepisów i obrzędów, a kategoria prawdy religijnej wydaje się w nich czymś raczej obcym. Dlatego zacznijmy od rozróżnienia religii, w których szuka się relacji i dialogu z Bogiem, oraz tych, które na dialogiczność przeżyć religijnych są raczej zamknięte.

Już Sokratesa mity nie interesowały, ale też nie chciał zajmować się ich obalaniem (por. Platon, Fajdros, 4; 229c-230a). Sądził on, że mity mają się nijak do podstawowych pytań o sens naszego życia i w żaden sposób nie pomagają nam w kształtowaniu samych siebie. Toteż, jego zdaniem, szkoda nawet czasu na demitologizowanie tych wierzeń, bo znajdują się one poza kategoriami prawdy i nieprawdy oraz pewności i niepewności, demitologizacja zaś byłaby próbą odczytania ich w tych właśnie, obcych im, kategoriach.

Dlatego zaś nie interesowały Sokratesa znajdujące się poza prawdą i nieprawdą wierzenia, bo znalazł on Boga naprawdę. Podczas procesu tak oto odpowiedział na zarzut, że „nie uznaje bogów, których państwo uznaje”

* O. prof. dr hab. Jacek Salij OP, kierownik Katedry Teologii Dogmatycznej na Wydziale Teologicznym Uniwersytetu Kardynała Stefana Wyszyńskiego w Warszawie, członek Komitetu Nauk Teologicznych Polskiej Akademii Nauk.

${ }^{1}$ Stosunkowo wiele korzystam tu z dwóch moich tekstów opublikowanych wcześniej: Wiara i wierzenia oraz Wiara świętujaca i wiara odświętna, w: J. Salij, Dylematy naszych czasów, Poznań 1998, s. 20-50. 
(Platon, Obrona Sokratesa, 11): „Ja ich uznaję, obywatele, jak żaden z moich oskarżycieli i pozostawiam Bogu i wam sąd o mnie; niech wypadnie tak, jak będzie najlepiej dla mnie i dla was" (tamże, 24).

Sądzę, że ten epizod z procesu Sokratesa należy odczytać w świetle platońskiego rozróżnienia doksa (mniemanie, wierzenie) i episteme (poznanie). Paradoksalnie, to nie Sokrates, ale jego oskarżyciele byli ateistami. Bogowie byli przedmiotem ich wierzenia (doksa). Tak naprawdę nie obchodziło ich nawet to, czy bogowie w ogóle istnieją. Dla nich liczyło się tylko to, że bogowie są uznawani przez państwo, a ich kult stanowi obowiązek obywatelski. Oskarżyciele przestraszyli się tego, że Sokrates odsłania epistemologiczną pustkę kultu państwowego. Ten strach tak ich sparaliżował, że w ogóle nie zrozumieli wielkiego odkrycia Sokratesa: Bóg istnieje naprawdę i jako taki jest przez nas poznawalny, czyli dostępny naszej episteme.

Religia antyczna - pisze znana jej badaczka - „zakłada skrupulatne wypełnianie wszystkich form kultu, ale nie wymaga wiary. Było prywatną sprawą człowieka, czy wierzył lub nie w bogów, którym składał ofiary. Natomiast samo składanie ofiar i przestrzeganie wskazówek wynikających z wróżb było jego obywatelskim obowiązkiem"'. Warto jednak zwrócić uwagę na to, że religie antyczne w ogóle nie znały pojęcia wiary. Jak twierdzą R. Bultmann i A. Weiser, terminów „wiara” (pistis) i „wierzyć” (pisteuein) klasyczna greka używa tylko w sensie świeckim³.

Znikomość związku między wierzeniami a prawdą i fałszem ujawnia się szczególnie wówczas, kiedy do religii, opartej na wierzeniach, próbuje się przymusić ludzi, którzy w Boga wierzą naprawdę. Ani podczas prześladowania Żydów w czasach machabejskich, ani w prześladowaniach chrześcijan przez kolejnych rzymskich cesarzy nie podejmuje się najmniejszej próby, żeby prześladowanych przekonać do wierzeń narzucanej im religii. Usiłowano jedynie wymusić na nich udział w kulcie, którego nie chcieli podjąć dobrowolnie. Organizatorzy prześladowań w ogóle nie zauważali niestosowności w kulcie, wymuszonym od ludzi, niepodzielających wierzeń ich religii.

Zdumienie, którego doświadczali wówczas zarówno prześladowani, jak i prześladowcy, stanowi miarę głębokiej różnicy między dwoma typami religii o tak diametralnie innym stosunku do prawdy. „Cóż w tym złego - pyta sędzia męczennika Polikarpa (+ 156) - że ktoś [...] składa ofiarę [bogom], by ratować swe życie?” (Męczeństwo Polikarpa, 8) „Któż wam broni - podpowiada tolerancyjnie prefekt aresztowanemu biskupowi Aleksandrii, Dionize-

\footnotetext{
2 M. Jaczynowska, Religie świata rzymskiego, Warszawa 1990, s. 10.

${ }^{3}$ R. Bultmann, $\pi \sigma \tau \varepsilon v \omega$, w: G. Kittel, G. Friedrich (red.), Theologisches Wörterbuch zum Neuen Testament, Stuttgart 1979, t. 6, s. 178n.
} 
mu (+ 265) - czcić waszego Boga, jeśli Go za Boga uważacie, razem z bogami [...] których znają wszyscy?” (Euzebiusz, Historia Kościoła, 7, 11, 9).

„Dlaczego, Grecy - z kolei w imieniu prześladowanych chrześcijan pyta około 170 roku Tacjan Syryjczyk - naciagacie na naszą szkodę ustawy państwowe, traktując nas niby jakichś zamachowców? [...] Jeśli ktoś nakazuje mi zaprzeć się Boga, to w tym jedynym wypadku nie będę posłuszny i raczej umrę, niż bym miał się okazać kłamcą i niewdzięcznikiem" (Przemowa do Greków, 4). „Ale u was - pisze w 197 roku Tertulian - prawnie wolno czcić wszystko oprócz Boga prawdziwego" (Apologetyk, 24, 10). I nie może Tertulian wyjść ze zdumienia, że kult religijny wymaga zezwolenia władzy państwowej: „Jeżeli Bóg człowiekowi nie spodoba się, nie będzie Bogiem. Wnet człowiek dla Boga będzie musiał być łaskawy" (tamże, 5.1).

Wyrażanie świata boskiego za pomocą wierzeń, sformułowanych poza prawdą i fałszem, było, jak się wydaje, czymś powszechnym w różnych religiach. To właśnie dlatego z taką łatwością ludy podbite porzucały swoje religie i przejmowały wierzenia i kult swoich zwycięzców. Również tutaj należy szukać przyczyn odwiecznej popularności różnych synkretyzmów religijnych.

W ten sposób doszliśmy do pierwszego przeciwieństwa między wierzeniami i wiarą: wiara przywiązuje do prawdy wagę najwyższą. Do tego stopnia - powie apostoł Paweł - że gdyby Chrystus nie zmartwychwstał naprawdę, my swoją wiarą w Jego zmartwychwstanie ciężko obrażalibyśmy Boga (por. 1 Kor 15, 14n). Wiara nie polega na tym, że ,jestem głęboko przekonany i mam pewność co do tego, że Chrystus zmartwychwstał”. Chrystus naprawdę zmartwychwstał! - to jest sama istota wyrastającej z wiary radości wielkanocnej.

Podobnie apostoł Piotr nie mówił: „My jesteśmy przekonani, że Ty jesteś Mesjasz, Syn Boga żywego”, on mówił: „,Ty jesteś Mesjasz, Syn Boga żywego!” (Mt 16, 16). Apostoł Jan bez ceregieli demaskował ,zwodzicieli, którzy nie uznaja, że Jezus Chrystus przyszedł w ciele ludzkim; taki jest zwodzicielem i Antychrystem" (2 J 7; por. 1 J 4, 3). Apostoł Paweł napisał nawet, że ,gdybyśmy nawet my lub anioł z nieba głosił wam Ewangelię różną od tej, którą wam głosiliśmy - niech będzie przeklęty!” (Ga 1, 8). Powtórzmy: o wierze nie rozstrzyga przekonanie o prawdzie tego, czego ona dotyczy, ale to, iż rzeczywiście dotyczy ona prawdy.

\section{Elementarne warunki dialogu wierzących z niewierzącymi}

Dialogiczność wiary religijnej realizuje się przede wszystkim w relacjach Boga z ludźmi. Zanim jednak ten temat podejmę, spróbujmy uporządkować niepokoje, jakie może budzić powyższe objaśnienie na temat wiary. 
Wydaje się ono gruntownie obce naszej pooświeceniowej mentalności. Zastrzeżenia formułowane przez tę mentalność są mniej więcej następujące:

Czy nie mamy tu do czynienia z przywłaszczaniem sobie właściwości ponadludzkich? Bo czyż zwyczajny człowiek może mieć aż tak bezpośredni dostęp do prawdy, że potrafi nie dać się zamknać w swoich własnych przeświadczeniach, które przecież tylko częściowo może weryfikować? Czy ludzie wierzący nie mogliby pogodzić się z tym, że ich wiara sprowadza się jednak do wierzeń, tym tylko różnych od wierzeń zwyczajnych, że przyjętych z największym przekonaniem i pewnością? Innymi słowy: niech ludzie wierzący przestaną wreszcie drażnić niewierzących oraz wierzących inaczej swoim „Chrystus zmartwychwstał!”, niech trochę spokornieją i niech mówią: „My jesteśmy przekonani, że Chrystus zmartwychwstał”.

W Europie od trzech już stuleci funkcjonują kulturowe mechanizmy, przymuszające wierzących do przeżywania swojej wiary na tym właśnie poziomie. W dominujących mass mediach jest dziś dogmatem, że sfera religijna znajduje się poza prawdą i fałszem, a przeświadczenie Kościołów, że nauczają prawdy objawionej przez Boga, stanowi zwyczajną uzurpację. Tę nowo-starodawną postawę wobec religii wyrażono w prostych, dających się rozpowszechniać formułach, że ,religii przyznajemy wolność, ale religia to sprawa prywatna” oraz że „wszystko jedno, jak człowiek wierzy, byleby dobrze postępował".

Powiedzmy to symbolicznie: zwyczajną niesprawiedliwością byłoby zakazywać komukolwiek radowania się z tego powodu, że Chrystus zmartwychwstał, i przymuszać go do ograniczenia swojej radości w formule, że ja tylko jestem przekonany, iż Chrystus zmartwychwstał. Zwolennicy takich rozwiązań zazwyczaj nie zdają sobie sprawy z tego, że przymuszanie ludzi wierzących do takich samoograniczeń oznacza $\mathrm{w}$ gruncie rzeczy przymuszanie ich do tego, żeby wyrzekli się swojej wiary.

$\mathrm{W}$ praktyce, te nowo-starodawne rozwiązania problemu religijnego wyrażają się coraz bardziej szczelnym zamykaniem religii w wyznaczonych jej niszach, coraz głębiej sięgającym zakazem modlitwy w świeckich miejscach publicznych, usuwaniem z przestrzeni publicznej znaku krzyża oraz innych symboli religijnych itp. Trudno nie zauważyć, że tak rozumiana „wolność religijna" opiera się na agresywnym antychrześcijańskim dogmacie, że „Boga nie ma i być Go nie może”. Właśnie w imię tego „dogmatu” - zresztą nie zawsze wywieszanego na sztandarach - wyrzuca się możliwie wszelkie przejawianie się wiary z przestrzeni publicznej, wpychając je w jakieś nisze. Nisze te mają być, oczywiście, coraz ciaśniejsze, no bo przecież „Boga nie ma i być Go nie może".

„Dogmat” ten znajduje również swoich teoretycznych apologetów. Filozofowie Koła Wiedeńskiego ostentacyjnie odmawiali zdaniom religijnym 
wręcz zdolności wyrażania sensu (innymi słowy, traktowali je jako pusty treściowo bełkot), a jeden z nich opublikował Indeks wyrazów zakazanych, w którym umieścił wszystkie kluczowe terminy języka religijnego, łącznie z wyrazem „Bóg”. Dziś antyreligijne hasła inspirowane książką Richarda Dawkinsa, Bóg urojony, wypisuje się nawet na miejskich autobusach.

Sytuacja stała się podobna, jak w czasach starożytnych prześladowań chrześcijaństwa. Dominująca mentalność, podobnie jak wtedy, chciałaby swoją postawę wobec pytań ostatecznych wyrażać w różnorodnych i znajdujących się poza prawdą i fałszem wierzeniach. Podobnie jak wtedy, zwolennicy różnych wierzeń okazują sobie wzajemnie daleko idącą tolerancję. I podobnie jak wtedy, dominująca mentalność nie potrafi zrozumieć, czym naprawdę jest wiara, i ma ogromne kłopoty z tolerowaniem ludzi wierzących. Niezgoda ludzi wierzących na zamknięcie swej wiary w sferze samych tylko poglądów w różnorodny sposób piętnowana jest jako postawa irracjonalna oraz jako potencjalne źródło fanatyzmu religijnego i zagrożenie dla wzajemnej tolerancji. W imię tak pojmowanej tolerancji rośnie w naszych czasach nietolerancja wobec niezagrażających nikomu przejawów wiary.

Otóż wydaje się, że autentyczny pokój społeczny wierzących z niewierzącymi, a nawet różnorodny dialog między nimi, jest nie tylko możliwy, ale łatwy do osiagnięcia, zwłaszcza jeżeli na jego straży będzie stało sprawiedliwe prawo. Wszyscy - wierzący i niewierzący - powinni stanowczo wykluczyć jakiekolwiek narzucanie innym swojego stanowiska, powinni również wykluczyć wszelki prozelityzm za pomocą nieuczciwych środków miękkich. Niewierzącym wolno, rzecz jasna, trzymać się dogmatu, że „Boga nie ma i być Go nie może". Wydaje się jednak, że bardziej racjonalnym poglądem człowieka niewierzącego na temat poznawczych możliwości wiary jest postawa następująca: „Wprawdzie nie wiem, czy Bóg jest, ale jeżeli jest, to nie mogę wykluczyć, że wiara w Niego daje jakieś nieznane mi możliwości poznawania Go".

\section{Czy w ogóle możliwy jest dialog człowieka z Bogiem?}

Doszliśmy do momentu, kiedy możemy wreszcie w sposób poważny postawić pytanie: Czy w ogóle możliwy jest dialog człowieka z Bogiem? Przełomowym wydarzeniem było tu objawienie biblijne, toteż odpowiedź na to pytanie będzie zupełnie inna dla religii biblijnych niż niebiblijnych. (Religiami biblijnymi są judaizm oraz chrześcijaństwo, kulturowo zaś do religii biblijnych należy włączyć również islam, gdyż powstał on w kręgu bardzo wyraźnych wpływów żydowskich i chrześcijańskich). 
Od razu pragnę z całą stanowczością zaznaczyć, że tezę powyższą traktuję jako faktograficzną i nie jest moją intencją doktrynalne kontrastowanie religii niebiblijnych z biblijnymi. Mówiąc inaczej: gdyby wskutek pogłębienia się naszej znajomości religii niebiblijnych okazało się, że w nich również stwierdzić należy różnorodne przejawy dialogowania z Bogiem, szukania Go, zbliżania się do Niego i kochania Go - nie mielibyśmy żadnych powodów, żeby takim faktom przeczyć. Raczej przeciwnie, fakty takie przyjęlibyśmy z radością, jako nowe i niespodziewane potwierdzenie prawdy, że „Bóg naprawdę nie ma względu na osoby, ale w każdym narodzie miły jest $\mathrm{Mu}$ ten, kto się Go boi i postępuje sprawiedliwie" (Dz 10, 34).

Niemniej, zgodnie z obecną naszą znajomością różnych religii, wydaje się, że autentyczny dialog człowieka z Bogiem zaistniał dopiero w religiach biblijnych. Zauważmy najpierw, że nie ma takiego dialogu w religiach panteistycznych lub panteizmem skażonych (tych mianowicie, gdzie bogowie są personifikacjami sił natury, bytów społecznych lub stanów psychicznych). Nawet jeżeli teksty kultowe tych religii mają niekiedy postać kierowanej do boga apostrofy, to ich sens wydaje się podobny, jak sens wezwań kierowanych do Polski czy do Orła Białego w naszych wierszach patriotycznych.

Owszem, wyznawcy religii politeistycznych - nawet jeżeli nie przykładają wagi do tego, czy ich bogowie istnieją, czy nie - zazwyczaj wyobrażają ich sobie jako żywe istoty, niekiedy nawet do nich się modlą. Jednak, jak twierdzi Mircea Eliade, człowiek wówczas ,nie śmie nawet pragnąć, by jego modlitwy mogły zrodzić jakąś zażyłość z bogiem"4.

Również myśl, że jakiś bóg mógłby nas kochać lub chcieć się z nami zaprzyjaźnić, nawet do głowy nie przychodzi wyznawcom tych religii.

Bogowie mogą lubić czy nawet kochać konkretne jednostki - pisze Włodzimierz Langauer, wybitny znawca religii starożytnych Greków - nigdzie jednak nie spotkamy śladów miłości bóstwa do człowieka w ogóle, do wszystkich ludzi żyjących na ziemi. Bogowie mają bowiem pełne poczucie swej odrębności, a do ludzi odnoszą się z lekceważeniem i wyraźnym chłodem. Te słabe, niepozorne, niemądre, śmiertelne istoty nie należą do ich świata. W gruncie rzeczy obustronny stosunek ludzie-bogowie nacechowany jest tym samym chłodem. Nigdzie nie spotkamy myśli, że człowiek ma do bóstw odnosić się z miłością i tego samego może od nich oczekiwać. Pobożność grecka nie ma nic wspólnego z miłością. Stosunek człowieka do boga to stosunek słabszego do silniejszego. Podobnie rzecz się ma i z drugiej strony: bogowie zdają sobie sprawę ze swojej potęgi i dlatego wymagają od ludzi czci5.

\footnotetext{
${ }^{4}$ M. Eliade, Historia wierzeń i idei religijnych, Warszawa 1988, t. 1, s. 184.

${ }^{5}$ W. Langauer, Religijność starożytnych Greków, Warszawa 1994, s. 168n.
} 
Przeświadczenie, że dystansu, jakim oddzielony jest człowiek od bóstwa, w żaden sposób nie da się przekroczyć, jest - jak się wydaje - wspólne wszystkim religiom niebiblijnym. Wyznawcom tych religii nigdy by nie przyszło do głowy to, co jest oczywiste dla wyznawców religii związanych z objawieniem biblijnym: żeby za pomocą modlitw i ofiar, choćby nawet i codziennych, szukać przyjaźni z Bogiem. Oni modlili się i składali ofiary, bo starali się w ten sposób uśmierzyć gniew bogów oraz zapewnić sobie ich opiekę. Tak ukształtowana religijność nie tylko nie odczuwała potrzeby regularnego kontaktu z Bogiem, ale nieraz doświadczała lęku, aby nadmiernym naprzykrzaniem się Bogu nie wzbudzić w Nim podejrzeń, że próbujemy się z Nim spoufalić, i nie narazić się w ten sposób na Jego gniew. Wiele świadectw tego lęku znajdziemy między innymi w tekstach starogreckich.

Dopiero biblijne objawienie, że człowiek został stworzony na obraz i podobieństwo samego Boga, i że Bóg pierwszy szuka przymierza i przyjaźni z ludźmi, wprowadziło przewrót w kształtowanie się naszych stosunków z Bogiem. W zasięgu naszej wyobraźni pojawiła się możliwość, a nawet powinność codziennej modlitwy oraz częstego, przypadającego regularnie co kilka dni świętowania jako podstawowych sposobów naszego zbliżania się do Boga i pielęgnowania naszej z Nim przyjaźni. Jak wiadomo, żadna z religii Dalekiego Wschodu - ani hinduizm, ani konfucjanizm, ani buddyzm, ani szintoizm - żadna też z pierwotnych religii czarnej Afryki czy Indian amerykańskich nie zna święta, które byłoby analogiczne do żydowskiego szabatu, chrześcijańskiej niedzieli czy muzułmańskiego piątku; w przestrzeganych na co dzień przez wyznawców tych religii przepisach i obserwancjach nie znajdziemy też żadnych codziennych modlitw, żadnego szukania kontaktu z Bogiem.

Przy okazji warto zauważyć, że współczesne zjawisko odchodzenia od praktyk religijnych ma wiele cech zwyczajnego regresu do dawnej religijności pogańskiej, kiedy to człowiek w zasadzie uznawał Pana Boga, liczył na Jego opiekę i od czasu do czasu uciekał się do Niego za pomocą religijnych aktów, ale do głowy by mu nigdy nie przyszło, żeby się z Bogiem zaprzyjaźnić.

Już ludzie Starego Testamentu zauważali tę głęboką odmienność swojej religii w stosunku do różnych religii pogańskich: „któryż naród wielki - entuzjazmuje się autor Księgi Powtórzonego Prawa - ma bogów tak bliskich, jak Pan, Bóg nasz, ilekroć Go wzywamy?" (Pwt 4, 7).

Pismo Święte często mówi o tym, niespotykanym w innych religiach, Bożym pragnieniu, żeby człowiek stał się Jego przyjacielem. Już o Henochu i Noem czytamy, iż żyli „w przyjaźni z Bogiem” (Rdz 5, 22. 24; 6, 9). Poruszająco brzmią modlitwy, w których ludzie przypominają Bogu, że nie wolno Ci, Boże, zapomnieć o tym, że Abraham, nasz praojciec, to przecież 
Twój przyjaciel (por. Dn 3, 35; 2 Krn 20, 7). Największych mistyków ogarnia święta zazdrość, kiedy się dowiadują o tym, że „Pan rozmawiał z Mojżeszem twarzą w twarz, jak się rozmawia z przyjacielem" (Wj 33, 11). Ale Boska oferta przyjaźni nie jest ograniczona do osób wyjątkowych: „Pan przyjaźnie obcuje z tymi, którzy się Go boją, i powierza im swoje przymierze" (Ps 25, 14). Prorok Izajasz w imieniu całego ludu wyśpiewuje swoje zafascynowanie Boskim Przyjacielem: „Chcę zaśpiewać memu Przyjacielowi pieśn o Jego miłości ku swojej winnicy!” $(5,1)$. Krótko mówiąc, nawet gdyby w Piśmie Świętym nie było przykazania, ażeby Boga kochać ,z całego swego serca, z całej duszy swojej, ze wszystkich swych sił" (Pwt 6, 5), człowiek biblijny tak właśnie starałby się Go kochać.

W Piśmie Świętym znajduje się wiele niezwykle odkrywczych obrazów tego niepojętego przybliżenia się Boga do ludzi. „Góry otaczają Jeruzalem; tak Pan otacza swój lud" (Ps 125, 2). Bóg porównuje się do ptaka, który uczy swoje pisklęta prawdziwej wolności, a w razie potrzeby chroni je pod swymi skrzydłami (Wj 19, 4; Ps 17, 8; 36, 8; 57, 2; 61, 5; 63, 8; 91, 4). Jest jak pasterz, który „pasie swą trzodę, gromadzi ją swoim ramieniem, jagnięta nosi na swej piersi, owce karmiące prowadzi łagodnie" (Iz 40, 11; por. Ps 23). Bóg jest porównywany nawet do pielęgniarki, mimo że język starohebrajski nie zna jeszcze tego wyrazu: swojego wiernego sługę „Pan pokrzepi nawet na łożu boleści, podczas choroby poprawi mu posłanie" (Ps 41, 4). Szczególnie wymownie brzmi porównywanie się Boga do kochającej matki, która pochyla się z miłością i troską nad swoim dzieckiem: „Pociągnąłem ich ludzkimi więzami, a były to więzy miłości. Byłem dla nich jak ten, co podnosi do swego policzka niemowlę - schyliłem się ku niemu i nakarmiłem go" (Oz 11, 4; por. Iz 66, 13; Ps 27, 10).

Nie jest głównym naszym celem przedstawianie zbliżania się Boga do ludzi w Starym Testamencie, dlatego nie wchodźmy głębiej w pojawiającą się tam nieraz ojcowską (por. Pwt 32, 6; Iz 63, 16), a poniekąd nawet macierzyńską symbolikę Boga (por. Lb 11, 12; Ps 22, 10n; Iz 49, 15). Nie tu również miejsce na szczegółowe przypominanie biblijnych wątków, że Bóg czuje się małżonkiem swojego ludu (por. Jr 2, 2; Oz 2, 16) oraz Goelem, czyli najbliższym krewnym, który wziął na siebie obowiązek przychodzenia nam z pomocą w chwilach zagrożenia (por. Wj 6, 6; Jr 50, 34). Nie będziemy tu również przedstawiać licznych starotestamentalnych świadectw przebywania Boga ze swoim ludem lub z poszczególnymi swoimi wybranymi (por. Pwt 4, 7; Ps 73, 28). Dość sobie uprzytomnić, że w Biblii sięga się po chyba wszystkie rodzaje pozytywnych więzi rodzinnych i przyjacielskich, ażeby pokazać relacje miłości, jakimi Bóg chciałby się z nami związać. Takie myślenie o Bogu było zupełnie niedostępne wyznawcom religii niebiblijnych. 
Otóż całe to doświadczenie Boga jako Kogoś Bardzo Bliskiego domagało się zupełnie nowej struktury kultu religijnego. Jest religijną oczywistością, że ze strony człowieka należy się Bogu coś w rodzaju wzajemności: jeśli Bóg raczył się do nas tak bardzo przybliżyć, to i my winniśmy się zbliżać do Boga. Regularność modlitwy, kultu i świętowania wyraża na sposób ludzki nasze pragnienie, że chcielibyśmy nieustannie być blisko Boga i w Jego świętej obecności przeżywać zmieniające się koleje naszego losu. Zbliżanie się bowiem Boga do nas jest zbliżaniem się do ludzi, a nie do przedmiotów; nie jest czymś automatycznym, Bóg oczekuje od nas dowodów, że nam na Jego bliskości zależy. „Przystąpcie bliżej do Boga, to i On zbliży się do was” - ujął to krótko apostoł Jakub (4, 8; por. Ps 145, 18).

\section{„Dialogiczność” Boga Trójjedynego}

Nigdy dość podkreślania, że inicjatorem dialogu Boga z ludźmi jest Bóg. „Bóg pierwszy nas umiłował” (1 J 4, 19), wybrał nas i umiłował ,przed założeniem świata" (Ef 1, 4). Szczytowym darem Jego miłości do nas jest, oczywiście, równy $\mathrm{Mu}$ w bóstwie Jego Syn: „Tak Bóg umiłował świat, że Syna swego jednorodzonego dał, aby każdy, kto w Niego wierzy, nie zginął, ale miał życie wieczne" (J 3, 16; por. $1 \mathrm{~J}$ 4, 10).

A ponieważ, jak to zauważył już święty Grzegorz z Nazjanzu, takie są Boże obyczaje, że najpierw obdarza i dopiero wtedy daje nam rozumieć swój dar, dopiero dzięki Jezusowi Chrystusowi - Synowi Bożemu, który z miłości do nas stał się jednym z nas - poznaliśmy prawdę Trójcy Świętej. Bo dopiero w świetle tajemnicy Trójcy możemy jako tako uchwycić, co jest ostatecznym celem misji Jezusa Chrystusa.

Otóż tajemnica Boga Trójjedynego, w największym skrócie, sprowadza się do następującego pytania: Jak to możliwe, że jeden, jedyny i niepodzielny Bóg jest trzema realnie odrębnymi Osobami? W teologii na to pytanie odpowiada się następująco: Osoby Boskie są wzajemnie sobie bliskie bliskością niemożliwą do osiągnięcia między osobami stworzonymi - aż tak całkowicie, że nie ma między Nimi (tak jak w miłości międzyludzkiej) wzajemnych relacji, ale każda z Osób jest cała i bez reszty, całą nieskończonością swojego bóstwa, hipostatyczną relacją ku dwom Osobom pozostałym.

Bóg Prawdziwy - Ojciec i Syn, i Duch Święty - jest wspólnotą Osób tak całkowicie i bez reszty na siebie otwartych, że bluźnierstwem byłoby o Nich powiedzieć: trzej bogowie. Trzy Osoby są jednym jedynym Bogiem, w którym poszczególne Osoby, przenikając się wzajemnie bez reszty, nie zatracają bynajmniej swojej osobowej odrębności. Przeciwnie: Ich odrębność właśnie polega na całkowitym oddawaniu się wzajemnym, tak że dla każdej 
z Nich jest ono niepowtarzalne - w taki sposób, że tylko pierwsza Osoba jest Ojcem, tylko druga jest Synem i tylko trzecia jest Duchem Świętym.

Bóg Ojciec kocha swego Syna, przedwiecznie, całą nieskończonością swojego bóstwa; Syn - całą nieskończonością swojego bóstwa, które przecież jest również Jego bóstwem - kocha swego Ojca. A ta ich Miłość to nie są dwie miłości, ale wspólna im Obu, jedna Miłość, osobowa, nieskończona. Ta ich Miłość jest równym im Obu i odrębnym od nich Obu Duchem Świętym.

\section{Ontyczny dialog stworzenia ze Stwórcą}

Dopiero teraz możemy jasno pokazać, że nie tylko my, stworzenia osobowe, aniołowie i ludzie, ale również nierozumne, znajdują się w sytuacji dialogicznej wobec swojego Stwórcy. Uno et eodem Verbo Pater dixit se et omnem creaturam - twierdzi święty Tomasz. Tym samym przedwiecznym Słowem, które jest Jego jednorodzonym Synem, wypowiada Ojciec samego siebie oraz całe stworzenie. Ewangelista Jan powie po prostu, że przez Słowo, które jest Bogiem, „wszystko się stało” (J 1, 1-3). Rzecz jasna, akt stworzenia wszystkiego jest zaledwie odblaskiem boskiego zrodzenia Syna, w niczym Jego boskości niewzbogacającym. W porządku boskich pochodzeń Syn jest Słowem absolutnie, w porządku stworzenia - jest skierowanym ku stworzeniom Słowem Bożej wszechmocy i miłości. Natomiast w porządku wcielenia i zbawienia - „Słowo ciałem się stało”, przyszło do nas jako Słowo Bożego miłosierdzia i pojednania nas z Bogiem.

Spójrzmy zatem na ten „dialog”, jaki prowadzą ze swoim Stwórcą nawet stworzenia nierozumne. Ponieważ w żadnym stworzeniu nie ma nic pozytywnego, co by nie pochodziło od Stwórcy, jest to dialog z natury swojej całobytowy. Mianowicie Stwórca nieustannie udziela każdemu stworzeniu istnienia oraz wszystkiego, czym ono jest, natomiast stworzenie jest nieustannie zwrócone całe sobą ku Stwórcy, aby otrzymywać od Niego całego siebie. W tym sensie w myśli chrześcijańskiej mówi się o modlitwie przyrody czy nawet całego kosmosu. Przyroda i kosmos przez to, że istnieją głoszą chwałę Stwórcy, tzn. są miejscem obdarzającej, stwórczej obecności Boga.

Stworzenia rozumne zostały powołane do istnienia jako byty zdolne do wolności i miłości. Ich całobytowe zwrócenie się ku Stwórcy musi się więc dokonywać zgodnie z tą ich naturą, tzn. w wolności i w miłości. Zanim jednak stanie się to możliwe, przedtem stworzenie rozumne musi siebie od Stwórcy otrzymać. Nawet Stwórca nie jest w stanie sprawić, żeby sam akt powołania do istnienia dokonał się w sposób dialogiczny, gdyż metafizyczną niemożliwością jest uzyskanie od nieistniejących jeszcze stworzeń rozum- 
nych, żeby zwróciły się ku Stwórcy jako ku źródłu swojego istnienia; najpierw muszą zostać stworzone i dopiero jako już istniejące mogą się świadomie, w wolności i miłości, zwracać ku swojemu Stwórcy.

Z powyższego wynika, że tylko stworzenia nierozumne mogą od pierwszego momentu swojego istnienia mieć pełnię własnej prawdziwości bytowej. Stworzenie rozumne uzyskuje ją dopiero w momencie wolnego i miłosnego całoosobowego zwrócenia się ku Stwórcy. Duchy czyste mogły już w pierwszym akcie swojego działania otworzyć się całoosobowo na Stwórcę lub całoosobowo przed Nim zamknąć. Człowiekowi - ze względu na jego cielesność - jest bez porównania trudniej zaktualizować do końca swoją zdolność do wolności. Zarówno otwieranie się, jak zamykanie na Stwórcę dokonuje się w nas stopniowo i coraz głębiej. Zamykanie się na Stwórcę, dopóki nie nastąpi zamknięcie ostateczne, nie sprowadza więc na człowieka potępienia wiecznego, lecz do niego prowadzi, jest grzechem. Z drugiej zaś strony, otwieranie się na Stwórcę, dopóki nie obejmie nas całych bez reszty, nie stanowi jeszcze całej odpowiedzi, jaką stworzenie rozumne może udzielić swojemu Stwórcy, lecz jedynie do niej prowadzi, jest modlitwą.

Krótko mówiąc, przez modlitwę należy rozumieć to wszystko, co w obecnej naszej sytuacji pielgrzymów w drodze do celu ostatecznego stanowi wolne i miłosne zaakceptowanie naszej dialogiczności w stosunku do Stwórcy. To otwieranie się na Stwórcę dokonuje się wszystkimi możliwymi aktami naszych władz wyższych i niższych, aby do końca przyjąć od Niego samego siebie i z kolei samemu oddać się Mu bez reszty. Przeciwieństwem modlitwy jest grzech, którego istota na tym polega, że człowiek niszczy w sobie zdolność do opisanego wyżej dialogu ze Stwórcą.

Zauważmy głęboką zgodność z powyższą koncepcją modlitwy całoosobowej klasycznego podziału na modlitwę uwielbienia i dziękczynienia, przebłagania i prośby. Modlitwa uwielbienia zaczyna się od miłosnego zachwytu, że Bóg jest taki, jaki jest; z zachwytu zaś płynie pragnienie, aby zanurzyć się w Nim bez reszty. Modlitwa dziękczynienia ma kierunek odwrotny. U jej podstaw leży tęsknota, żeby dary Boże przyjąć w całej ich wspaniałości. W pewnym momencie człowiek uświadamia sobie, że wszystkie dary rzeczowe, jakich Bóg nam udziela, podporządkowane są darom osobowym.

I tak darem Bożym dla mnie jestem ja sam: nieustannie otrzymuję od Boga samego siebie. Modlitwa dziękczynienia uwrażliwia mnie na to, żeby przyjmować z rąk Bożych samego siebie możliwie w całej pełni, tzn. żeby nie zatracić nic z tego piękna, w które Stwórca postanowił mnie wyposażyć, lecz w miarę możliwości zachować je i rozwijać. Następnie, wielkim darem Bożym, który powinien spontanicznie wywoływać we mnie dziękczynienie i troskę o pełne przyjęcie, są inne osoby, zwłaszcza najbliżsi: współmałżonek, dzieci, rodzice, mój anioł stróż, przyjaciele, ludzie potrzebujący mo- 
jej pomocy. Największym zaś darem Boga dla mnie, pobudzającym mnie do maksymalnego dziękczynienia i coraz pełniejszego przyjmowania, jest oczywiście On sam: trzeba nam całego życia na tej ziemi, a może jeszcze i czyśćca, żeby przyjąć ten Najwspanialszy Dar całą swoją osobową pojemnością.

Również modlitwa przebłagania dokonuje się nie tylko słowami i czynami, ale ma tendencję ku temu, żeby wyrażać się całoosobowo. Przebłaganie jest to pokorne wyznanie Bogu miłości przez kogoś, kto się jej sprzeniewierzył. Przez grzech człowiek zniszczył w sobie zdolność do całoosobowego zwrócenia się ku Stwórcy; w modlitwie przebłagania grzesznik prosi Boga, aby nie pozostawił go samemu sobie, aby raczył przywrócić mu zdolność kochania swojego Stwórcy. Modlący się w ten sposób grzesznik chciałby powrócić na drogę coraz głębszego otwierania się na Boga. Zatem trudno sobie wyobrazić, żeby rzetelna modlitwa przebłagalna ograniczała się do samych tylko słów; logika tej sytuacji domaga się, aby grzesznik starał się wówczas modlić z takim zaangażowaniem samego siebie, na jakie tylko go stać.

Budowanie teorii modlitwy na prawdzie o naszej ontycznej dialogiczności wobec Stwórcy pomoże też głębiej zrozumieć sens modlitwy prośby. Cała przestrzeń, w której żyjemy, wypełniona jest różnorakimi darami Bożymi. Co więcej, Pan Bóg gotów jest obdarzać nas coraz bardziej, żeby wreszcie - w życiu wiecznym - zaspokoić całkowicie nasze pragnienia bezpośrednio darem z samego siebie.

Czy w tej sytuacji - gdy jesteśmy nieustannie i ponad miarę obdarzani przez Boga - modlitwa prośby ma w ogóle sens? Oczywiście, że ma, i to tak wielki, że modlitwy błagalnej nie da się zastapić żadną inną formą modlitwy. Mianowicie nasze pragnienia darów Bożych niekoniecznie odzwierciedlają obiektywną, pochodzącą od Boga, hierarchię tych darów. Niektórych Bożych darów możemy pragnąć jakby autonomicznie, bez odniesienia do Daru Ostatecznego, a może nawet przeciwko niemu. Modlitwa prośby jest miejscem oczyszczania naszych pragnień, ich otwierania na Pragnienie Ostateczne. Zapewne dlatego Pan Jezus zachęcał nas do wytrwałości w naszych prośbach do Boga. Zatem jeśli na dnie każdej prośby, nawet prośby o rzeczy najbłahsze, musi znajdować się prośba o wiekuiste zjednoczenie z Bogiem, trudno sobie wyobrazić, aby prośby nasze mogły polegać tylko na słowach albo na odgrywaniu wobec Pana Boga roli petenta. W miarę możliwości winniśmy prosić Boga całymi sobą.

Rzecz jasna, nie powinno się mianowicie zdarzyć, że ktoś, odkrywając modlitewny wymiar pracy, czynienia dobra czy samego nawet człowieczego istnienia, zacznie bagatelizować modlitwę jako działanie specyficzne, odrębne od wszystkich innych naszych działań. Postawmy sobie pytanie, dlaczego 
- skoro wszystkie nasze działania i samo bytowanie człowieka może mieć sens modlitwy - nie powinno w naszym życiu codziennym zabraknąć czasu poświęcanego wyłącznie modlitwie? Odpowiedź na to pytanie jest stosunkowo prosta.

Po pierwsze, do Boga możemy mówić „Ty”, jest On osobowym partnerem dialogu. Otóż z osobą można nawiązywać różnoraki kontakt pośredni. Dopóki jednak nie dojdzie do kontaktu bezpośredniego, różne formy kontaktu pośredniego stwarzają jedynie warunki do dialogu, sam dialog nie dochodzi do skutku. Warunkiem zaistnienia prawdziwego dialogu jest bezpośredni kontakt obu stron; dopiero jego mocą inne formy kontaktu mogą uzyskać charakter dialogu.

Spróbujmy dla wyrażenia powyższej myśli odwołać się do porównania. Pytać o sens oddawania się działaniom, które są wyłącznie modlitwą, to tak samo jak pytać o sens świadomości w psychice ludzkiej, skoro przecież również w innych wymiarach naszej psychiki realizuje się nasze życie osobowe. Byłoby oczywiście czymś absurdalnym wątpić w sens świadomości. Świadomość jest przecież szczególnie ważnym miejscem naszego życia osobowego, w którym ujawniają się i krystalizują nasze osobowe postawy i w którym najłatwiej można korygować błędy naszych postaw osobowych. Ten podstawowy sens ludzkiej świadomości znakomicie wyjaśnia Victor Frankl w swojej rozprawce Podświadomy Bóg. Otóż te działania, które nie zawierają w sobie innego sensu oprócz modlitwy, stanowią jak gdyby świadomą warstwę naszego dialogu z Bogiem: w modlitwie sensu stricto ujawnia się i krystalizuje nasz osobowy stosunek do Boga, najłatwiej też wówczas dokonywać korekty w swoich postawach wobec Boga.

Po wtóre, poświęcając jakąś cząstkę naszego życia wyłącznie modlitwie, wyznajemy w ten sposób transcendencję Boga wobec wszelkiego dobra, jakim na tej ziemi możemy Go uczcić. Czyniąc dobro, szukając prawdy, pochylając się nad najbardziej potrzebującymi, urzeczywistniamy w ten sposób swoje zwracanie się ku Bogu, który nas uzdolnił do czynienia dobra, prawdy i miłosierdzia. „Albowiem kto nie miłuje brata swego, którego widzi, nie może miłować Boga, którego nie widzi. Takie zaś mamy przykazanie od Niego, aby ten, kto miłuje Boga, miłował też i brata swego" (1 J 4, 20n). Zarazem jednak nie jest to jeszcze całe dobro, jakie może się przeze mnie ujawnić. Zostałem przecież stworzony dla Dobra Nieskończonego, którym jest sam Bóg. Tak samo jak miłość rodzicielska jest czymś nieporównanie więcej niż troską o spełnienie rozmaitych potrzeb dziecka, podobnie nasze zwracanie się ku Bogu winno być czymś więcej niż pełnieniem rozmaitego miłego Bogu dobra. To „,coś więcej” najwyraźniej manifestujemy przez takie działania, które nie mają żadnego innego celu, jak tylko po prostu okazanie Bogu miłości. 
Skoro modlitwę określam jako wolne i miłosne akceptowanie naszej dialogiczności wobec Stwórcy, o dwóch jeszcze zagadnieniach trzeba koniecznie wspomnieć. Po pierwsze, dialog polega nie tylko na wzajemnym przekazywaniu sobie słowa, ale również na wzajemnym otwieraniu się na słowo płynące od partnera. Słuchanie jest w dialogu ważniejsze nawet niż mówienie. Również w modlitwie ważniejszą rzeczą wydaje się słuchać Boga niż do Niego mówić. Otóż Boga słucha się znacznie inaczej niż człowieka. Bóg jest przecież wszechobecny i wszystko podtrzymuje w istnieniu, od Boga nieustannie otrzymujemy całych siebie i jest On bliższy nam niż my sami sobie. Zarazem Bóg jest transcendentny wobec każdego miejsca i wobec największej nawet doskonałości stworzonej. Wynika stąd, że wszystko ja sam, moi bliźni i cały świat - jest przepełnione głosem Bożym, a zarazem że Bóg mówi do nas zawsze jakby więcej, niż nawet najlepsi spośród nas są w stanie usłyszeć. Bóg przemawia do nas zarówno jako nieustannie działająca Opatrzność, jak przez księgę natury i głos sumienia. Zarazem choćbyśmy byli bezgrzeszni i najdoskonalsi, nie bylibyśmy w stanie usłyszeć głosu Bożego do końca. W każdym świadectwie Bożej Opatrzności i w każdym Bożym przykazaniu jest coś niezgłębionego: głos ten płynie bowiem od nieskończonego Boga.

W tym miejscu nasuwa się następne zagadnienie. O ile mowa Boża do człowieka jest zawsze niezgłębiona, to słyszymy ją bardziej lub mniej wyraźnie w zależności od duchowej sytuacji zarówno nas samych, jak i społeczności, w których żyjemy. Podstawową przeszkodą, utrudniającą nam słuchanie przemawiającego do nas Boga, jest grzech. Tak więc po raz drugi, od innej strony, dochodzimy do twierdzenia, że przeciwieństwem modlitwy jest grzech. To grzech jest główną przyczyną tego, że niekiedy całym społeczeństwom zaczyna się wydawać, jak gdyby Bóg się ukrył, zamilkł lub nawet umarł. A zatem pojawił nam się następny wielki temat, którego już nie będę rozwijał: że człowiek może utracić zdolność do dialogu ze swoim Stwórcą.

Ale ten temat prowadzi nas już prosto do Jezusa Chrystusa, a więc do rozpatrywania modlitwy na płaszczyźnie dzieła odkupienia.

\section{Dialog synów i przyjaciól z Ojcem}

Syn Boży przyszedł do nas oczywiście nie tylko po to, aby naprawić w nas zniszczenia dokonane przez grzech, tzn. aby przywrócić nam utraconą zdolność do wolnego, miłosnego i dającego życie wieczne zwrócenia się ku Stwórcy. Po to przyszedł również. Przede wszystkim jednak przyszedł po to, żeby dać nam udział w swoim Bóstwie i wprowadzić nas w wewnętrzną tajemnicę Trójjedynego. 
O tym, że Trójca Przenajświętsza jest nieskończonym, do końca zrealizowanym, a zarazem nieustannie trwającym Dialogiem, już mówiliśmy. Co z tego wynika dla naszego rozumienia modlitwy? Po pierwsze, w zupełnie nowych perspektywach zaczyna nam się jawić tajemnica mowy Bożej do człowieka. Bogu mało było przemawiać do nas przez księgę przyrody, przez działania swojej Opatrzności i głos naszego sumienia; mało $\mathrm{Mu}$ nawet było przemawiać przez natchnione słowa Pisma. Postanowił przemówić do nas przez swojego Syna. Przez Niego, przez Przedwieczne Słowo Boże, świat został stworzony. Teraz przez to samo Słowo, które stało się ciałem, świat ma zostać naprawiony. Krótko mówiąc, Ojciec Przedwieczny, przemawiając do nas w różnorodny sposób, w gruncie rzeczy chce powiedzieć nam jedyne Słowo, ale za to jakie Słowo! - to Słowo, które jest jednorodzonym Synem, równym w bóstwie Ojcu i Duchowi Świętemu. Wypowiada Je, rzecz jasna, w Duchu Świętym, tzn. w osobowej, Boskiej Miłości, która jest pieczęcią Jego niepojętej z Nim jedności. W tym jednym jedynym Słowie - tzn. w żywym Synu Bożym, który dla nas stał się człowiekiem i za nas umarł na krzyżu oraz zmartwychwstał - streszcza się całe Pismo Święte i cała mowa Boża, zawarta w dziele stworzenia.

Odpowiedzią z naszej strony na tak wielką miłość powinno być pragnienie, abym i ja cały bez reszty stał się słowem miłości do Boga. Ponieważ taka przemiana nie leży w zasięgu mojej mocy, powinienem ubiegać się o to, aby Bóg raczył mnie tak do końca wypełnić swoją miłością, żeby nie było we mnie nic, co by nie było skierowane ku Niemu. Inaczej mówiąc: Podobnie jak Bóg wielorako przemawia do człowieka, ale w gruncie rzeczy wypowiada do nas tylko jedno jedyne Słowo, tzn. samego siebie - tak samo wszystkie nasze modlitwy, działania i postawy winny być ku temu skierowane, żebym ja sam stał się cały bez reszty jednym słowem miłości do Boga. Rzecz jasna, tylko łaska Chrystusowa może nas do tego uzdolnić.

I więcej jeszcze. Swoje Słowo wypowiedział Przedwieczny Ojciec do każdego z nas, ale zarazem do całego rodu ludzkiego. Cały ród ludzki - i każda ze składających się nań społeczności - winien się przemieniać w jedno słowo odpowiedzi na miłość Bożą. Chodzi oczywiście o taką jedność, która nie zniszczy tożsamości poszczególnych osób, ale właśnie pozwoli każdej z osób odsłonić się w całej swojej niepowtarzalnej oryginalności. Na tym właśnie polega tajemnica Kościoła. W tym miejscu aż się prosi o rozwinięcie tematu, że modlitwa jest duszą międzyludzkiej miłości oraz warunkiem osiągnięcia pełni tożsamości, do której Stwórca powołuje każdego z nas. Niestety, w jednym artykule nie da się powiedzieć wszystkiego, co by się chciało.

Najważniejszej prawdy o modlitwie jeszcze nie powiedzieliśmy. Mianowicie nawet nasze przemienienie się w słowo odpowiedzi na miłość Bożą 
ani nawet przemienienie się całego Kościoła w jedno słowo miłości do Boga, nie stanowi ostatecznej perspektywy naszego otwarcia się na dialog z Bogiem. Bóg w swojej niepojętej miłości do nas postanowił dać nam cząstkę w swoim wewnętrznym Dialogu, we wzajemnym udzielaniu się Osób Boskich. Mianowicie postanowił uczynić nas jedno ze swoim Synem, dać nam uczestnictwo w Jego Boskim Synostwie; chce, abyśmy byli - przez całą wieczność - Jego mistycznym Ciałem. To dzieło łączenia nas w jedno z jednorodzonym Synem Bożym zaczęło się już teraz.

Dlatego też, jak w perspektywie ostatecznej refleksja nad modlitwą znajduje swoje uwieńczenie w nadziei na wiekuiste włączenie nas w Boże synostwo Jednorodzonego, tak na tej ziemi szczytem naszego dialogowania z Bogiem jest udział w ofierze i uczcie eucharystycznej. Albowiem w Eucharystii Ten, który oddaje nam się bez reszty, czyni nas podobnymi do siebie uczestnikami swojej Boskiej natury. Nasze uczestnictwo w Eucharystii jest najgłębszym, przez samego Boga dawanym świadectwem, że już teraz stanowimy w jakiś sposób jedno $z$ jednorodzonym Synem Bożym - i możemy mieć udział w tym Dialogu, jaki odbywa On - w Duchu Świętym - z Przedwiecznym Ojcem. Zarazem dzięki Eucharystii nasze przebóstwienie rośnie do tej miary, jaka została nam wyznaczona na życie wieczne.

\section{Dialogical dimension of the religious faith (Summary)}

Dialogical character of religious faith is realized primarily in the relationship between God and men. It seems that a genuine dialogue with God came to be only in the Biblical religions. There is no such dialogue in pantheistic religions, or pantheism or contaminated (that is those in which gods are personifications of the forces of nature, social entities or mental states).

The initiator of this dialogue is God himself. "God loved us first" $(1 \mathrm{Jn} 4,19)$, chose us and loved us "before the world was made" (Ep 1,4). Already in the Old Testament, God's relations with men are presented in the image of all the positive family relationships: God wants to be like father to us, like mother, like a spouse, and Goel (next of kin, required to come to help in a desperate situation). The Bible is probably the only holy book in which there is the idea of the covenant of God with men.

The crowning gift of His love for us is, of course, His Son equal to Him in the divinity: God loved the world so much that He gave His only Son, so that everyone who believes in Him may not be lost but may have eternal life (cf. 1 Jn 3,16; Jn 4,10). 
The experience of God as Someone very close required an entirely new structure of worship. It is obvious in religion that on the part of man there must be an answer to God's love: if God deigned to come so close to us, we should also come close to God. The regularity of prayer, worship and celebration expresses in human terms our desire to be always close to God and in His holy presence to go through our lives. 
